УДК 331:159.942.3

DOI https://doi.org/10.32689/maup.psych.2021.1.2

\title{
Антоніна ГРИСЬ
}

доктор психологічних наук, професор кафедри психології, ПрАТ «ВНЗ «Міжрегіональна Академія управління персоналом», вул. Фрометівська, 2, м. Київ, Україна, 03039

ORCID: 0000-0002-0153-2303

\section{Марія ПАВЛЮК}

доктор психологічних наук, професор кафедри психології, ПрАТ «ВНЗ «Міжрегіональна Академія управління персоналом», вул. Фрометівська, 2, м. Київ, Україна, 03039

ORCID: 0000-0002-0822-8128

\section{Mariia PAVLIUK}

Doctor of Psychological Sciences, Professor at the Department of Psychology, Interregional Academy of Personnel Management, 2 Frometivska str., Kyiv, Ukraine, 03039 ORCID: 0000-0002-0822-8128

\section{Antonina HRYS}

Doctor of Psychological Sciences, Professor of the Department of Psychology, Interregional Academy of Personnel Management, 2 Frometivska str., Kyiv, Ukraine, 03039 ORCID: 0000-0002-0153-2303

\section{ТИПИ КОМПЕТЕНТНОСТЕЙ ПСИХОЛОГА ПРИ РОБОТІ ІЗ КРИЗОВИМИ СТАНАМИ У КЛІЕНТІВ

\author{
TYPES OF COMPETENCES OF PSYCHOLOGIST \\ WHEN WORKING WITH CRISIS STATES IN CLIENTS
}

У статті подано результати дослідження актуальної для сучасної педагогічної та вікової психології, теоретичної та консультативної психологї̈ проблеми - розвиток типів компетентностей фахівців для роботи з кризовими категоріями клієнтів. Проаналізовано підходи до вивчення типів компетентностей у укранській та зарубіжній психологічній теорії і практиці. Метою статті є висвітлення результатів дослідження ефективності розвитку професійних компетентностей психологів під час викладання навчальних дисииплін, щзо розкривають специифіку роботи психолога з кризовими станами у клієнтів.

Обтрунтовано застосування кейс-методів у процесі підготовки майбутніх психологів для розвитку фахових компетентностей та інтеграції взаємозв'язків між ними. Показано ефективність розвитку різних типів компетентностей, щуо підтверджено результатами підсумкових тестів.

Ключові слова: типи компетентностей, аутопсихологічна компетентність, сочіально-психологічні компетентності, професійна компетентність, кризові стани, кейс-методи.

The article presents the results of research of the problem relevant for modern pedagogical and age psychology, theoretical and consultative psychology - the development of types of competencies of specialists to work with crisis categories of clients. Approaches to the study of types of competencies in Ukrainian and foreign psychological theory and practice are analyzed. The purpose of the article is to highlight the results of a study of the effectiveness of the development of professional competencies of psychologists in the teaching of disciplines that reveal the specifics of the work of a psychologist with crisis situations in clients.

The use of case methods in the process of training future psychologists for the development of professional competencies and the integration of relationships between them is justified. The efficiency of development of different types of competencies is shown, which is confirmed by the results of final tests.

Keywords: types of competencies, autopsychological competence, socio-psychological competencies, professional competence, crisis states, case methods.

Актуальність дослідження. В наш час у багатьох 3ВО та наукових установах тривають акредитації освітньо-професійних та освітньонаукових програм, які мають свої особливості у залежності від типу навчального закладу та інтересу стейкголдерів. Ключовими під час захисту освітніх програм є компетентності та програмні результати навчання. Серед основних 
критичних зауважень НАЗЯВО до програм, що акредитуються $\epsilon$ відсутність специфіки регіону у якому знаходиться навчальний заклад. А також затребуваність фахівців на сучасному ринку праці, що відображало б особливості освітніх програм. На наш погляд вельми актуальною на сьогоднішній день була б освітньо-професійна чи освітньо-наукова програма підготовки майбутніх фахівців-психологів до роботи 3 кризовими станами у клієнтів. Окільки як засвідчує наш досвід психологічної практики нині усе більше осіб опиняються у складних життєвих обставинах через алкогольну залежність одного 3 членів сім’і, надмірну залученість батьків у власну професійну діяльність чи навпаки їх безробіття, інші труднощі економічного, соціального та психологічного характеру, що значно утруднює процес соціально-психологічної адаптації особистості.

Саме тому у рамках даної статті ставимо за мету висвітлити на прикладі розроблених програм навчальної дисципліни «Кризове консультування» та «Психологія роботи 3 соціально дезадаптованими неповнолітніми» їх ефективність у контексті розвитку професійних компетентностей для роботи 3 кризовими станами у клієнтів.

Але спершу звернімося до самого компетентісного підходу та до тих напрацювань вчених, які могли б пролити світло на зміст підготовки майбутніх психологів для роботи у цьому вузькоспеціалізованому напрямку.

Перш ніж описувати деталізовано різні підходи до вивчення компетентності слід зауважити, що стосовно роботи із кризовими клієнтами у практиці професійної діяльності знадобляються різні типи компетентностей, що пов'язано із тим, що причинами криз можуть бути як біологічні, соціальні, психологічні, психофізіологоічні, педагогічні та соціокультурні чинники, які висувають вимогу залученості фахівців різних галузей та міжпрофесійну комунікацію.

Виклад основного матеріалу. Компетентність особистості є міждисциплінарним поняттям і досліджується у психології, філософії, соціології, педагогіці. Нині розмежовуються поняття компетентності у діяльності та компетентності як особистісні утворення. Розуміння терміну компетентності залежить від зосередженості дослідників на тих чи інших аспектах означеного поняття.

Теоретичні основи компетентнісного підходу викладено у працях Б.Г. Ананьєва, І.С. Булах, П.Я. Гальперіна, В.Г. Кременя, О.М. Леонтьєва, С. Д. Максименка, А. К. Маркової, Дж. Равена, Н.В. Чепелєвої, В.Д. Шадрикова та ін.
Аналізуючи поняття «компетентність» i «компетенція», автори вважають, що компетентність суб'єкта залежить від прояву в дії умінь, навичок та інших якостей, які $\epsilon$ основою компетентності, від їх вживання в реальній ситуації, в якій опиняється носій компетенції [2]. Іншими словами, поняття «компетенція» використовується в літературі тоді, коли йдеться про результати виконання завдань та їх відповідність стандартам, підкреслюючи практичну дієву сторону («знаю, як»). Тоді як поняття «компетентність» використовується для характеристики суб'єкта i включає особистісні якості («знаю, що»). В цьому випадку компетентність визначається як досягнутий особистістю рівень володіння необхідними, компетенціями, що забезпечують заданий стандарт ефективності вирішення нею професійних завдань.

Серед зарубіжних вчених, які займалися вивченням компетентностей Nash, J. M., and Larkin, K. T. (2012), Neubert, J. C., Maintert, J., Kretzschmar, A., and Greiff, S. (2015), Rodolfa, E., Baker, J., DeMers, S., Hilson, A., Meck, D., Schaffer, J., et al. (2014). Так у зарубіжній психології одні автори пов'язують компетентність iз базовими характеристиками індивіда, які зумовлюють успіхи в певних видах активності, інші - зі здібностями, особистісними характеристиками, особистісними рисами та набутими знаннями. Так, Д. Мак Клелланд розуміє під компетентністю деякі базові особистісні характеристики, які детермінують ефективність дій у діяльності та в інших ситуаціях. T. Хоффман уважає, що поняття компетентності операціоналізується трьома способами: як видимі і фіксовані результати діяльності; як деякі стандарти виконання тих чи інших операцій і як особистісні властивості, що визначають ефективність діяльності.

Ю.Г. Татур [6] характеризує компетентність як здатність особистості використовувати отриману у процесі навчання базу для успішної професійної діяльності. Компетентний спеціаліст з вищою освітою знає не лише як зробити (уміння), але і чому треба зробити саме так, «здатен здійснити вибір з арсеналу своїх умінь, які найкращим чином відповідають умовам даної ситуації».

Ю.В. Варданян розглядає компетентність як складну систему внутрішніх психічних властивостей і станів особистості фахівця, його готовності до здійснення професійної діяльності і здібності (тобто вміння та можливості) виробляти необхідні для цього дії [1].

Компетентність виступає не структурою або рівнем розвитку, а якістю психічних процесів. 3 цієї, точки зору, компетентність 
виявляється психологічною системою забезпечення якості і має такі властивості: можливість розвитку, причому розвитку за допомогою формування індивідуального стилю діяльності, комплексною будовою (єдність емоційних, мотиваційних i когнітивних структур), а також наявністю екзистениійноі складової (існування в нереальному просторі та часі).

У рамках цієї статті актуальним є трактування не лише поняття компетентності, а й психологічної готовності, а саме як психічного стану, що являє собою єдність емоційно-вольових, пізнавальних і мотиваційних компонентів, які забезпечують можливість успішних дій фахівця. Основна відмінність психологічної готовності до діяльності від компетентності, на думку Н.М. Яковлєвої (1992), виявляється у часовій перспективі. Якщо готовність спрямована в майбутне і своєю функцією покликана прогнозувати успішність вирішення завдань, то компетентність - підсумок освоєння знань, умінь і навичок, що забезпечують рівень вирішення проблем у професійній діяльності.

Для успішної роботи $з$ кризовими клієнтами, на першому місці на наш погляд є такий тип компетентності як аутопсихологічна компетентність, що являє собою компетентність психолога у своїх внутрішніх переживаннях, станах, ідентифікаціях. Бо саме від того, як психолог сам справляється зі своїми внутрішніми процесами, у тому числі кризовими станами, залежатиме ефективність його роботи $з$ таким клієнтом. Аутопсихологічна компетентність передбачає також розуміння переваг та недоліків власної діяльності та особистості.

Слід відмітити, що від того як психолог сам оговтується від власних пережитих травматичних подій та кризових станів, віднаходить у них нові значення та смисли, інтегрує їх у ядерні смислові структури власної особистості, усвідомлює нові життєві цінності, сам змінюється детермінує кількість і якість перетворень у самого клієнта.

Компетентність, на думку В. Ф. Спірідонова, вбирає в себе як знання, вміння та навички, певний рівень розвитку різних здібностей, які забезпечують високі результати, так і професійне ставлення, яке описується в термінах самооцінки (У. Джемс, К. Леві), рівня домагань (Ф. Хоппе) і самоефективності (А. Бандура). Також В. Ф. Спірідонов (2000) уважає, що розвинена компетентність пов'язана із володінням певною професійною мовою і набором якихось спеціальних уявлень чи «схем», у тому числі про самого себе.
Знання психолога про самого себе, його самоставлення $\epsilon$ надзвичайно важливими із кризовими клієнтами. Оскільки кризові стани $\epsilon$ свого роду перевіркою клієнта на міцність і витривалість його соціального, фізичного i духовного Я. На відповідність клієнта новій ситуації розвитку.

Для того, щоб подолати успішно кризовий стан особистості необхідно концентрувати усі свої зусилля навколо вирішення актуальних задач, які постають у кризовій ситуації. Забезпечення позитивної інтеграції для клієнта відбувається тоді, коли у особистості є сили, навики організації власної активності для подолання труднощів, а також здатність їх інтеграції у єдине ціле у даний конкретний момент часу.

Якщо ж сил у клієнта недостатньо, компетентний психолог може активізувати зовнішніх і внтурішніх помічників як на метафоричному, так і на реальному рівні. У символдрамі, або кататимно імагинативній психотерапії $\mathrm{X}$. Льойнера у багатьох образах пропонується задіювати силу та потенціал помічників для роботи з проблемою клієнта.

Для позитивної динаміки та інтеграції кліснта після переживання кризових станів необхідними є навики усвідомлення, самоконтролю та саморегуляції.

Кризовий стан пов'язаний із фрустрацією i нагадує хірургічне втручання у структуру особистості. I саме під час переживання кризових станів у особистості розхитуються системи зовнішніх опор (образ і стан свого тіла, їжа, одяг, соціальний статус, смисли і цінності), які є чимось зовнішнім по відношенню до психічної реальності (В.В. Козлов, 2007). Саме у результаті переживання кризових станів якраз і $є$ можливість виявити, що $\epsilon$ стрижнем у структурі цієї особистості, а що щезає одразу, як тільки стає відсутньою зовнішня підтримка.

Наступною важливою компетентністю для психолога-практика є соціально-психологічна компетентність. Р.В. Овчарова [3] розуміє ii як здатність психолога використовувати знання й уміння для вирішення практичних завдань $з$ метою організації ефективної взаємодії з клієнтом (групою) на основі правильного оцінювання (аналізу) ситуації, своїх психологічних особливостей та особливостей клієнта (групи). Структура соціально-психологічної компетентності майбутніх психологів включає в себе мотиваційно-ціннісний, операційний та функціональний компоненти.

I.O. Зимня виділяе три основні групи компетентностей: компетентність, що стосується самого себе як особистості; компетентність, пов'язана із взаємодією з іншими; компетент- 
ність, що стосується діяльності, які виявляються у всіх їі типах і формах [2].

М.М. Обозовим виокремлюється комунікативна компетентність, що може бути визначена в двох аспектах: як орієнтованість особистості в різних ситуаціях спілкування, заснована на знаннях і чуттєвому досвіді, і як здатність ефективно взаємодіяти з оточуючими завдяки розумінню себе й інших при постійному змінюванні психічних станів, міжособистісних відносин і умов соціального середовища [4].

В.Г. Ромек [5] розглядає соціальну компетентність як результат особливого стилювпевненої поведінки, при якому навички впевненості автоматизовані і дають можливість гнучко змінювати стратегію і плани поведінки з урахуванням вузького (особливості соціальної ситуації) і широкого (соціальні норми та умови) контексту.

Таким чином, як бачимо більшість авторів, звертаючись до різних видів компетентностей так чи інакше розглядають компетентість з точки зору якості психічних процесів та станів, властивостей особистості. Незалежно від того, які класифікаційні основи різних видів компетентностей - це все одно внутрішні особистсні характеритики майбутнього фахівця.

Для того, аби відбулося привласнення особистістю професійних компетентностей, також дуже важливо задіювати особистий досвід здобувачів вищої освіти та їхні кейси з реального життя, аби методи роботи з кризовими станами відчував кожен на собі та зміг оцінити їх дієвість та ефективність.

У процесі викладання дисциплін практичного спрямування, якими є зазначені вище курси неможливо обійтися без застосування ситуаційних задач із реального практичного досвіду роботи з кліснтами, які перебувають у кризових станах.

Окрім кейсів важливо також поєднувати ï застосування із міжнародними класифікаціями хвороб, таких як (МКБ - 10, OPD - 2, DSM-V), щоб майбутні психологи змогли чітко відокремити свою сферу компетенції при роботі з кризовими станами у клієнтів та своєчасно адресувати клієнтів до тих фахівців, які у тандемі із ними зможуть більш успішно допомогти клієнту справлятися із кризовими станами.

Поєднучи такі теоретичні та практичні знання у практиці викладання навчальних дисциплін можна забезпечити більш високий рівень різних типів компетентностей у процесі підготовки психологів до практичної діяльності.

Нами було проведено дослідження у різних групах студентів-психологів (у кількості
60 осіб) на базі державних та приватних 3ВО м. Києва під час викладання дисциплін «Кризове консультування» та «Психологія роботи 3 соціально дезадаптованими неповнолітніми», в рамках яких було застосовано як власний практичний досвід роботи 3 кризовими клієнтами, так і досвід інших психологів-практиків, що працюють у різних модальностях психотерапії та мають практичний досвід роботи із складними категоріями клієнтів. А також задіяно психотравматичний досвід самих студентів (за бажанням, участь у створенні власних кейсів студентами була добровільною), оскільки серед студентів є значна частина тих, хто не готовий розкриватися у рамках навчальних практичних та лабораторних занять. Водночас $є$ i багато охочих, які залюбки представляють свої життєві історії 3 тим, щоб краще у них розібратися та отримати зворотній зв'язок від групи.

Після проведення практичних та лабораторних занять із даних дисциплін студентам було запропоновано пройти тест на оцінку різних типів компетентностей, який складався із 50 запитань та кейс-випадку. Приклад тесту наводимо нижче.

Приклад тесту для перевірки сформованості у студентів різних типів компетентностей для роботи з кризовими категоріями клієнтів

1. До ресурсів особистості належать здібності, які дають можливість індивіду переживати відчуття стабільності і цілісності в різних ситуаціях і в різний час:

a) здатність переживати, переносити і інтегрувати сильні впливи;

б) ресурси Я (здібності, що дають змогу індивіду реалізовувати свої потреби і взаємодіяти з іншими людьми);

в) навички самоусвідомлення: інтелект, здатність до інтроспекції, сила волі, ініціативність, націленість на особистісне зростання, усвідомлення своїх потреб, здатність бачити перспективи;

г) усі відповіді вірні.

2. Цей комплекс досить поширений і породжений виключно стосунками між дітьми та батьками. В процесі розвитку особистості він виявляється у вигляді боягузтва, вимогливості, страху неприйняття, відчуття провини тощо.

a) комплекс Іони;

б) комплекс Електри;

в) Едипів комплекс;

г) комплекс Каїна.

3. Чинниками, що породжують агресивну поведінку можуть бути:

a) інтереси та цінності особистості;

б) тип темпераменту; 
в) делінквентна субкультура, антисоціальна спрямованість особистості;

г) усі відповіді вірні.

4. Ознаками агресивної поведінки можуть бути:

a) виражене прагнення до домінування над людьми і використання їх у своїх цілях;

б) тенденція до руйнування, спрямованість на завдання шкоди іншим;

в) схильність до насильства (завдання болю);

г) усі відповіді правильні.

г) сигналізації, орієнтації.

5. Для визначення норми у поведінці особистості застосовують наступні критерії:

a) статистичний;

б) психопатологічний;

в) віковий;

г) усі відповіді правильні.

6. Патологічними формами агресії можуть бути:
а) наслідування;
б) невроз;
в) психоз;
г) навіювання.

7. Визначення професійної придатності психолога для роботи 3 соціально дезадаптованими неповнолітніми здійснюється за такими критеріями:

а) фізичне та психічне здоров'я;

б) соціальний та емоційний інтелект;

в) адаптивність;

г) усі відповіді правильні.

8. Вираженість агресивної поведінки у формі короткотривалої реакції на конкретну ситуацію має назву:
a) активна агресивна поведінка;
б) пасивна агресивна поведінка;
в) ситуативна агресивна поведінка;
г) усі відповіді правильні. хологічного захисту належать:
а) індивідуальні особливості;
б) соціальна ситуація розвитку;
в) розвиток «Я».
г) усі відповіді правильні

9. До факторів формування механізмів пси-

10. Загальні закономірності процесу адаптації особистості відображені у концепції:

а) самоактуалізації (К. Роджерса);

б) стресу (Г. Сельє);

в) научіння (Б. Скіннер);

г) іншій (вкажіть якій).

11. Ознаками задоволеності-незадоволеності життям $€$ :

a) загальний емоційний стан у зв'язку 3 життєвою ситуацією;

б) динамічний компонент життєдіяльності (активність-пасивність, наявність устремлінь, бажань); в) задоволеність пов'язана 3 реалізацією планів, задоволення потреб;

г) усі відповіді правильні.

12. Для захисної поведінки дітей характерними є:

a) психологічний захист як результат негативного впливу 3 боку батьків та засвосння демонстрованих батьками форм поведінки;

б) психологічний захист як результат ігрової діяльності;

в) психологічний захист як результат конфліктної взаємодії з оточенням;

г) психологічний захист як результат інтерпретації досвіду.

13. До зрілих механізмів захисту належать:

a) реактивні утворення;

б) інтелектуалізацію;

в) сублімацію;

г) дисоціацію.

14. До нарцисичних механізмів належать:

a) заперечення;

б) проекція;

в) викривлення;

г) усі відповіді правильні.

15. Це складне багаторівневе явище включає в себе наступні основні компоненти:

1.) спостережувана аномальна поведінка, або симптом, наприклад, швидка стомлюваність, плач, спроби самогубства;

2.) мотиваційні порушення, що лежать в основ симптоматики, наприклад уникання будь-яких видів діяльності, або взагалі ухиляння від активної участі в процесі життя;

3.) система переконань, що стосується упевненості у безглуздості устремлінь, відсутність радощів і перспектив життя, власної ущербності, неповноцінності, приреченості, має назву:

a) тривожності;

б) депресії;

в) агресії;

г) інше.

16. Девіантними варіантами поведінки неповнолітніх при застосуванні механізму заперечення:

a) брехливість;

б) схильність до симуляції;

в) демонстрація спроб саморуйнівної поведінки;

г) усі відповіді правильні.

17. Психологічна стійкість це:

a) властивість особистості, що характеризує іiі поведінку у процесі напруженої діяльності;

б) складна якість особистості, в якій об'сднані: врівноваженість, стабільність, опірність; 
в) здатність утримувати рівень напруги, не виходячи за межі прийнятного адаптивного стресу

г) здатність протистояти труднощам, зберігати віру в ситуаціях фрустрації.

18. Виберіть один із варіантів механізму протікання психологічної травми:
а) ідентифікація;
б) рефлексія;
в) зціпеніння;
г) навіювання.
21. Наслідком психологічної травми може бути:

а) посттравматичний стресовий розлад;

б) компенсація;

в) гіперпротекція;

г) інший варіант (вкажіть який саме).

22. Один 3 основних типів реагування на психотравму є:
а) проекція;
б) застрявання;
в) компроміс;
г) прийняття. захисту належать:
a) фантазія;
б) рухова активність;
в) пасивно-агресивна поведінка;
г) усі відповіді правильні.

23. До незрілих механізмів психологічного

24. Ця стадія психологічної травми настає поступово і може тривати від кількох тижнів до кількох років - у випадку, якщо особистість з якихось причин залишається на даній стадії:
a) стадія заперечення;
б) стадія нав'язливостей
в) стадія відчаю;
г) стадія завершення.

25. Автором теорії прив'язаності, яка має дві протилежні тенденції: прагнення до нового до «небезпеки» та пошук підтримки і захисту є:

а) Дж. Боулбі;

б) М. Малер;

в) А. Біон;

г) А. Адлер.

26. Головна відмінність психотравми від усіх інших видів травм тіла полягає в тому, що:

a) час тут не лікус, а тільки посилюс негативний стан;

б) рана має інший зміст;

в) негативні почуття слабшають із часом;

г) розвиваються адаптивні стратегії поведінки.

28. При роботі з неповнолітніми, що пережили психологічну травму, необхідно враховувати такі їх особливості:

a) висока внутрішня напруга і пов'язаний 3 нею страх неконтрольованого емоційного вибуху; б) страх повернення до спогадів про подію, що викликає сильну душевну біль;

в) сильне спотворення сприйняття події, пов'язане з його емоційною насиченістю;

г) усі відповіді правильні.

29. Цей тип научіння випливає із уявлень, згідно з якими людина навчається новій поведінці не лише на основі власного, прямого досвіду, а й досвіду інших, спостереження за іншими людьми, тобто за рахунок процесів моделювання і має назву:

а) класичне обумовлювання;

б) оперантне обумовлювання;

в) соціальне научіння;

г) інструментальне научіння.

28. При роботі з травмованими неповнолітніми, які пережили необхідно дотримуватися таких правил:

a) створити для неповнолітнього безпечну, довірливу атмосферу;

б) намагатися якомога більше отримати інформації про травматичну подію;

в) одразу аналізувати найбільш складні моменти травми;

г) інше (вкажіть, яке саме правило).

29. Неконструктивними стратегіями подолання травми $\epsilon$ :

а) самозвинувачення;

б) ізоляція;

в) девіантна поведінка;

г) усі відповіді правильні.

30. Драматичний трикутник: жертварятівник-переслідувач запропонований:

a) Стівен Карпман;

б) Маргарет Малер;

в) Дональд Вудс Віннікот;

г) Альфред Біон.

31. Синдром вигорання - це:

a) фізичне, емоційне або мотиваційне виснаження, яке характеризується порушенням продуктивності праці та втомою, безсонням, підвищеною схильністю до соматичних захворювань;

б) процес, що розгортається у часі, довготривала стресова реакція, яка виникає внаслідок впливу на особистість хронічних професійних стресів середньої інтенсивності.

в) складова професійного вигорання, що визначає деформацію особистості професіонала;

г) усі відповіді правильні.

32. Ознаками емоційного вигорання є:

a) ірраціональні установки, цінності, стереотипи;

б) емоційне виснаження, деперсоналізація, редукція особистісних досягнень;

в) спрямованість, здібності характер;

г) розлади уяви, уваги, мислення та інших пізнавальних психічних процесів. 
33. Можливі девіації поведінки при регресії:

а) інфантилізм;

б) туніядство;

в) конформізм в антисоціальних групах та вживання психоактивних речовин;

г) усі відповіді правильні.

34. Резистентність (опірність) це:

a) здатність зберігати свободу поведінки і вибору способу життя, це самодостатність як свобода від залежності (хімічної, інтеракційної або поведінкової);

б) здатність до забезпечення успішної самореалізації, досягнення життєвих цілей; збереження працездатності; збереження здоров'я;

в) здатність до соціальної адаптації; збереження значущих міжособистісних зв'язків;

г) здатність протистояти труднощам, зберігати віру в ситуаціях фрустрації.

35. Чинники стресостійкості:

а) вербальна та невербальна агресія;

б) природжені особливості організму та ранній дитячий досвід, особистісні властивості, соціальне середовище;

в) тривожність та депресивні стани;

г) стратегії поведінки особистості у складних життєвих обставинах.

36. Психологічна травма це:

a) широкий комплекс різноманітних симптомів, що виникають у неповнолітніх під впливом сильного стресу, або шляхом накопичення регулярних стресових впливів різної інтенсивності;

б) глибокі і болісні переживання особистості, пов'язані із травматичними подіями їі життя;

в) рана, пошкодження, результат насилля;

г) усі відповіді правильні.

37. Вивчена безпорадність це:

a) стан невпевненості особистості за якого особистість переконана у своїй безпорадності, й у тому, що іiї дії не принесуть корисного результату;

б) стан особистості при якому вона навчилася поводитися безпорадно, навіть якщо з'являється можливість покращення ситуації після зникнення шкідливих обставин, в яких вона перебувала;

в) стан особистості, за якого вона відчуває брак своїх знань, умінь і навичок, а також на емоційному рівні переживає фрустрацію;

г) стан тривоги, туги та відчаю.

38. Автором, що запропонував поняття вивченої безпорадності є:
а) 3. Фрейд;
б) А. Мінделл;
в) Л. Марчер;
г) М. Селігман

39. Оптимальна психологічна межа це:

a) здатність особистості встановлювати діалогічні стосунки з близьким та віддаленим оточенням:

б) побудований в процесі життєвого шляху зусиллями самої особистості функціональний орган, що дозволяс їй здійснювати автентичну і адекватну реальності взаємодію зі світом;

в) випрацьований впродовж життєвого шляху паттерн поведінки, що характеризується сталістю та визначає спосіб поведінки особистості у різних типах взаємодії з оточенням;

г) дистанція на якій особистість почуває себе найбільш оптимально із значимими іншими у процесі міжособистісної взаємодії 3 ними.

40. Модель діяльності психолога із девіантами, що базується на розумінні психологічних механізмів функціонування Образу Я включає такі основні елементи:

a) Образ Я і психологічна травма;

б) Образ Я і механізми психологічного захисту;

в) образ Я і стосунки, цінності установки та поведінка;

г) усі відповіді правильні.

41. До основних властивостей психологічної межі особистості належать:

a) змінність, функціональність;

б) незмінність, субстанційність;

в) варіативність, морфологічність;

г) стабільність, урівноваженість.

42. Автором типології дітей із дисфункціональних сімей: фанат, герой сім'ї, благодійник, цап відбувайло, втрачена дитина є:

a) Енн Сміт;

б) Ерік Берн;

в) Стівен Карпман;

г) Ерік Еріксон.

43. Запропоновані нижче критерії оцінки стану пацієнта розроблені в рамках наступних класифікацій:

- переживання хвороби і передумов для iіi лікування;

- стосунки;

- конфлікт; тості;

- структурний рівень розвитку особис-

- психічні і психосоматичні порушення;

a) МКБ - 10;

б) DSM - IV;

в) OPD - 2;

г) Іншій (вкажіть якій).

Така система викладання навчальних дисциплін, яка передбачає завдання як теоретичного, так і практичного спрямування, дає змогу майбутнім психологам, зорієнтуватися 
Відмінності між показниками (М-середні арифметичні) експериментальної і контрольної груп до та після експерименту за шкалами тесту знань, умінь і навичок

\begin{tabular}{|c|c|c|c|c|c|c|c|c|}
\hline & \multicolumn{4}{|c|}{ Експериментальна група } & \multicolumn{4}{|c|}{ Контрольна група } \\
\hline & \multirow[t]{2}{*}{$\begin{array}{c}\text { До } \\
\text { (M) }\end{array}$} & \multirow[t]{2}{*}{$\begin{array}{c}\text { Післяя } \\
\text { (М) }\end{array}$} & \multicolumn{2}{|c|}{$\begin{array}{c}\text { W-критерій } \\
\text { знакових рангів } \\
\text { Уілкоксона }\end{array}$} & \multirow[t]{2}{*}{$\begin{array}{c}\text { До } \\
(\mathbf{M})\end{array}$} & \multirow[t]{2}{*}{$\begin{array}{c}\text { Після } \\
\text { (М) }\end{array}$} & \multicolumn{2}{|c|}{$\begin{array}{c}\text { W- критерій } \\
\text { знакових рангів } \\
\text { Уілкоксона }\end{array}$} \\
\hline & & & $\mathbf{Z}$ & $\mathbf{P}$ & & & $\mathbf{Z}$ & $\mathbf{P}$ \\
\hline $\begin{array}{c}\text { Результати } \\
\text { тестування } \\
\text { студентів }\end{array}$ & 76,9 & 85,8 & $-4,309$ & 0,000 & 75,4 & 72,3 & $-2,721$ & 0,007 \\
\hline
\end{tabular}

Таблиця 2

Відмінності між показниками (М-середні арифметичні) до та після тренінгу в експериментальній і контрольній групах за шкалами тесту знань, умінь і навичок

\begin{tabular}{|c|c|c|c|c|c|c|c|c|}
\hline & \multicolumn{4}{|c|}{ До } & \multicolumn{3}{|c|}{ Після } \\
\cline { 2 - 8 } & $\begin{array}{c}\text { Е-група } \\
\text { (M) }\end{array}$ & $\begin{array}{c}\text { K-група } \\
(\mathbf{M})\end{array}$ & $\begin{array}{c}\mathbf{Z}, \\
\text { Манна-Уітнi }\end{array}$ & $\mathbf{P}$ & $\begin{array}{c}\text { Е-група } \\
\text { (M) }\end{array}$ & $\begin{array}{c}\text { K-група } \\
\text { (M) }\end{array}$ & $\begin{array}{c}\mathbf{Z}, \\
\text { Манна-Уітні }\end{array}$ & $\mathbf{P}$ \\
\hline $\begin{array}{c}\text { Тест на знання, } \\
\text { уміння, навички }\end{array}$ & 76,9 & 75,4 & $-0,466$ & 0,641 & 85,8 & 72,3 & $-3,769$ & 0,000 \\
\hline
\end{tabular}

як у психодіагностичних інструментах, так і у психотерапевтичних інтервенціях у процесі роботи з кризами клієнтів. Важливими $є$ також тренінгові технології у роботі з психологами у напрямку їх підготовки до роботи 3 клієнтами, що опинилися у складних життевих осбтавинах.

Усі ці психолого-педагогічні впливи досить виразно позначилися на позначилися також на особливостях професійно важливих знань, умінь і навичок студентів - майбутніх психологів. Тестові показники в експериментальній і контрольній групі після експерименту відрізняються на статистично-значимому рівні $(\mathrm{p} \leq 0,000)$ : в експериментальній групі вони значимо зросли, а в контрольній - зменшилися.

Зафіксовані кількісні показники підтверджують ефективність впровадження запропонованої моделі підготовки психологів до роботи 3 кризовими клієнтами.

Після вивчення спецкурсів «Психологія роботи 3 соціально дезадаптованими неповнолітніми» та "Кризове консультуванння" тренінгових процедур, які тривали півроку, студенти продемонстрували достатній рівень знань про психологічні особливості соціально дезадаптованих неповнолітніх, принципи та підходи до роботи 3 ними, психологічні механізми корекції девіантної поведінки та виявили навички роботи з психологічною травмою, механізмами психологічного захисту, найближчим оточенням девіантів, їх установками та цінностями, які $\epsilon$ складовими образу Я особистості дезадаптованих неповнолітніх.

Отримуючи зворотній зв'язок від студентів, які вивчали дані навчальні дисципліни ми дійшли висновків, що у результаті ії вивчення у студентів не лише формуються професійноважливі якості для роботи з означеним контингентом та формуються знання, уміння i навички для роботи 3 кризовими категоріями клієнтів, а й у процесі його вивчення відбувається профілактика кризових явищ у соціальному середовищі на більш віддалену у часі перспективу. Так, деякі студенти наприклад відмічали, що їх дуже зацікавили питання ранньої травматизації дитини, що може стати причиною девіацій у майбутньому, а інших проблеми педагогічної занедбаності неповнолітніх, що характеризуються відсутністю систематичності у формуванні в підростаючої особистості цінних соціально-психологічних компетенцій, що дають змогу особистості успішно адаптуватися до мінливих умов соціального середовища.

\section{Література:}

1.Варданян Ю.В. Строение и развитие профессиональной компетентности специалиста с высшим образованием (На материале подготовки педагога и психолога) : дисс. ... доктора педагог. наук : 13.00.01, 19.00.07. Москва, 1998. 353 с.

2.Зимняя И.А. Ключевые компетенции как результативно-целевая основа компетентностного подхода в образовании : учебное издание. Москва : Исследовательский центр проблем качества подготовки специалистов, 2004. 40 с. (Серия : Труды методологического семинара «Россия в Болонском процессе : проблемы, задачи, перспективы»). 
3.Овчарова Р.В. Технологии практического психолога образования : учеб. пособ. для студентов вузов и практических работников. Москва : ТЦ «Сфера», 2000. 448 с.

4.Обозов Н.Н. Психологическая культура взаимных отношений : учебное пособие. Москва : Высшая школа. 1986. $45 \mathrm{c}$.

5.Ромек В.Г. Поведенческая психотерапия : учеб. пособие для студ. высш. учеб. заведений. Москва : Академия, 2002. 192 с.

6.Татур Ю.Г. Высшее образование: методология и опыт проектирования. Москва : Логос, Университетская книга, 2006. 153 с.

7.Crocker J. The pursuit of self-esteem: Implications for good and evil / J. Crocker, S.J. Lee, L.E. Park. A. G. Miller (Ed.), The social psychology of good and evil. New York: Guilford Press, 2004. P. 271-302. URL : http://wings.buffalo.edu/psychology/labs/SMRL/docs/Crocker,\%20Lee,\%20Park\%20 (2004,\%20 Chapter\%20in\%20Social\%20Psychology\%20of\%20Good\%20and\%20Evil).pdf.

8.Rodolfa, E., Baker, J., DeMers, S., Hilson, A., Meck, D., Schaffer, J., et al. (2014). Professional psychology competency initiatives: implications for training, regulation, and practice. S. Afr. J. Psychol. 44, 121-135. doi:10.1177/0081246314522371.

9.von Treuer KM and Reynolds N (2017) A Competency Model of Psychology Practice: Articulating Complex Skills and Practices. Front. Educ. 2:54. doi: 10.3389/feduc.2017.00054.

\section{References:}

1.Vardanyan, Yu.V. (1998). Stroenie i razvitie professional'noy kompetentnosti spetsialista s vysshim obrazovaniem (Na materiale podgotovki pedagoga i psikhologa) [Structure and development of professional competence of a specialist with higher education (On the material of teacher and psychologist training)]. Candidate's thesis. Moscow, 353 p. [in Russian].

2.Zimnyaya, I.A. (2004). Klyuchevye kompetentsii kak rezul'tativno-tselevaya osnova kompetentnostnogo podkhoda v obrazovanii: uchebnoe izdanie [Key competencies as an effective-target basis of a competencebased approach in education: educational publication]. Moscow: Research Center for the Problems of the Quality of Training of Specialists, 40 p. (Series: Proceedings of the Methodological Seminar "Russia in the Bologna Process: Problems, Tasks, Prospects") [in Russian].

3.Ovcharova, R.V. (2000). Tekhnologii prakticheskogo psikhologa obrazovaniya: ucheb. posob. dlya studentov vuzov i prakticheskikh rabotnikov [Technologies of practical education psychologist: textbook. manual. for university students and practitioners]. Moscow: TTs «Sfera», 2000. 448 p. [in Russian].

4.Obozov, N.N. (1986). Psikhologicheskaya kul'tura vzaimnykh otnosheniy: Uchebnoe posobie. [Psychological culture of mutual relations: Textbook]. Moscow: Vysshaya shkola. 45 p. [in Russian].

5.Romek, V.G. (2002). Povedencheskaya psikhoterapiya : ucheb. posobie dlya stud. vyssh. ucheb. zavedeniy. [Behavioral psychotherapy: textbook. manual for stud. higher. study. Institutions]. Moscow: Academy. 192 p. [in Russian].

6.Tatur, Yu.G. (2006). Vysshee obrazovanie: metodologiya i opyt proektirovaniya [Higher education: methodology and design experience]. Moscow: Logos, University book. 2006. 153 p. [in Russian].

7.Crocker J. The pursuit of self-esteem: Implications for good and evil / J. Crocker, S.J. Lee, L.E. Park. A. G. Miller (Ed.), The social psychology of good and evil. New York: Guilford Press, 2004. P. 271-302. Web: http://wings.buffalo.edu/psychology/labs/SMRL/docs/Crocker,\%20Lee, \%20Park\%20 (2004,\%20Chapter\%20 in\%20Social\%20Psychology\%20of\%20Good\%20and\%20Evil).pdf. [in English].

8.Rodolfa, E., Baker, J., DeMers, S., Hilson, A., Meck, D., Schaffer, J., et al. (2014). Professional psychology competency initiatives: implications for training, regulation, and practice. S. Afr. J. Psychol. 44, 121-135. doi:10.1177/0081246314522371. [in English].

9.von Treuer KM and Reynolds N (2017). A Competency Model of Psychology Practice: Articulating Complex Skills and Practices. Front. Educ. 2:54. doi: 10.3389/feduc.2017.00054 [in English]. 